University of Warwick institutional repository

This paper is made available online in accordance with

publisher policies. Please scroll down to view the document

itself. Please refer to the repository record for this item and our

policy information available from the repository home page for

further information.

To see the final version of this paper please visit the publisher's website. Access to the published version may require a subscription.

Author(s): Matthew Watson ; Colin Hay

Article Title: In the dedicated pursuit of dedicated capital: Restoring an indigenous investment ethic to British capitalism

Year of publication: 1998

Link to published version:

http://dx.doi.org/10.1080/13563469808406368

Publisher statement: None 
[as accepted for publication in New Political Economy, 4, 1998]

\title{
In the Dedicated Pursuit of Dedicated Capital: Restoring an Indigenous Investment Ethic to British Capitalism
}

\author{
Matthew Watson and Colin Hay
}

Published in New Political Economy, 3 (3), 1998, 407-426.

Tony Blair's landslide electoral victory on May 1 (New Labour Day?) presents the party in power with a rare, perhaps even unprecedented, opportunity to revitalise and modernise Britain's ailing and antiquated manufacturing economy. ${ }^{*}$ If it is to do so, it must remain true to its long-standing (indeed, historic) commitment to restore an indigenous investment ethic to British capitalism. In this paper we argue that this in turn requires that the party reject the very neo-liberal orthodoxies which it offered to the electorate as evidence of its competence, moderation and 'modernisation', which is has internalised, and which it apparently now views as circumscribing the parameters of the politically and economically possible.

In this context, New Labour enjoys an almost unique advantage: a mandate for change, reflected in its 179 seat overall majority, more fundamental than that it sought. Yet such a situation does present certain difficulties for a party whose manifesto and supporting policy documents contained, at best, a submerged radicalism couched within the rhetoric of competence, consensus and conciliation. ${ }^{1}$ The position, then, is one of opportunity and threat. Judged purely on the scale of defeat and the recriminatory ructions that currently engulf the Party, the Conservatives would appear consigned to the electoral margins for at least two terms. This provides Labour with a rare (and much-needed) opportunity to think long-term. Yet despite its best intentions, the situation is also that in which expectations of reform - and rapid reform at that - exceed both Labour's declared ambition and, in all likelihood, the capacity of a more resolutely radical government (with a clearly reforming manifesto and a mandate) to deliver. Moreover, despite the much-vaunted vibrancy of the British economy, difficult decisions face the newly incumbant administration. In particular these concern: (i) Europe and the relative costs (economic and political) of membership or exclusion from a European Single Currency in 1999 or some time thereafter; (ii) the relative 
wage-skill profile of the British labour market and hence the nature of the competitive position and mode of insertion of the national economy within European and global economic dynamics; and, perhaps more acutely still, (iii) Britain's distinctive lack of manufacturing investment, the paucity of its capital stock, the obsolescence of much of its beleaguered manufacturing capacity, and its characteristic shortfall of 'dedicated' capital. The most long-standing and, we argue, ultimately the most fundamental of these concerns is the third. Accordingly, this provides the principal focus of attention in this paper. Indeed, our argument is that by restoring an indigenous investment ethic to British capitalism, the terms by which we understand the insertion of the domestic economy within wider political and economic dynamics may be fundamentally recast.

Our central contention in what is to follow is that if New Labour is to demonstrate the economic competence of its electoral convictions, it must first rediscover the political courage of its former policy convictions, challenging (and ultimately rejecting) the terms by which that competence has come to be understood. Indeed, more broadly, it must transcend the pervasive neo-liberal paradigm that has come to circumscribe the parameters of what is considered politically and economically feasible, possible and desirable in Britain as elsewhere. Though sacrificed or, on a more favourable reading, relegated to the Downsian electoral imperative that seemingly came to dominate the revision of policy in the pre-election period, traces of precisely such an alternative economic and political vision can still be identified in the Party's (albeit diluted) proposals on industrial, regional and financial reform. Originating in the Policy Review itself, they were associated in particular with the Shadow DTI under the tutelage of first Bryan Gould and, subsequently, Robin Cook. Yet the contradictions evident between this more dirigiste conception of a supply-side 'developmental state' and the developing fiscal fortitude of the Shadow Treasury Team have clearly been resolved, for the time being, in favour of the latter. ${ }^{2}$ Our aim in this paper is to return to the former, to reclaim the potentially radical and, within the context of neo-liberal economics, heretical core of New Labour's erstwhile industrial and regional strategy, and to review critically the political and economic alternatives available to New Labour once the shackles of the neo-liberal paradigm have been cast off.

In what follows we concern ourselves with the problem (for problem it is) of productive investment. We concentrate in particular on policy priorities for the expansion of manufacturing capacity and the rejuvenation of the productive economy through the restoration of an indigenous investment ethic to British capitalism. Yet before considering the space for alternatives, it is first important to consider the broader diagnosis of the affliction to which such reforms must constitute a response, and the distinctiveness and intractability of this British condition. 


\section{Lacking dedication: The pathologies of British capitalism}

The argument that British capitalism is distinctive, exceptional even, has a long and distinguished pedigree amongst critics of the left for whom its characteristic pathologies can be traced to the peculiar dislocation of financial and industrial capital and the persistent ascendancy of the former. It is associated in particular with the so-called 'Anderson-Nairn theses', published in a series of instalments in New Left Review from the early 1960s. ${ }^{3}$ In recent years the argument has received something of a revival, being dusted off and repackaged in the form of Will Hutton's blistering polemic, The State We're In, and its somewhat more conciliatory sequel, The State to Come. ${ }^{4}$ The argument is elegant in its simplicity. Britain's distinctive pathologies can be traced ultimately to the incomplete nature of its bourgeois revolution. Lacking the creative destruction of a genuinely revolutionary upheaval, Britain's precocious capitalism inherited much of its institutional architecture and cultural distinctiveness from the feudal era. These peculiarities of primacy were to become what they remain today — fetters on continued economic development and capital accumulation.

In the current context, these generic tendencies of British capitalism are reflected in a body of company law which discourages long-term strategic investment, a macroeconomic policy-making process that institutionalises the interests of financial over industrial capital, and a banking system in which capital is rarely available to industry in the long-term on a competitive basis. The result is an economy emphasising finance over manufacturing, and overseas over domestic investment. It is characterised by pervasive underemployment, low wages, a massive skills deficit, and a vicious circle of low productivity growth, low investment and lack of innovation.

It is easy to see how such a diagnosis of the British affliction might inform proposals for institutional particularly financial - reform. Yet it is important to note that advocates of systematic attempts to address Britain's distinctive manufacturing investment shortfall have not relied exclusively on such a formulation. The so-called Cambridge School have, in particular, drawn upon the work of comparative political economists who identify clear clusterings in the institutional arrangements of otherwise distinct 'national capitalisms' in making their own case for institutional reform. ${ }^{5}$ Thus, prominent in discussions of industrial performance and under-investment in Britain (and perhaps increasingly so) has been the comparison drawn between the 'Anglo-US model' of capitalism on the one hand, and the 'German-Japanese' or 'NippoRhenish model' on the other. ${ }^{6}$

Despite their obvious similarities, there are important differences between these two approaches. The theorists of British exceptionalism have developed a general analysis of what they take to be the specificity of British capitalism. This allows them, for instance, to trace the arcane and anachronistic character of 
British democracy (as reflected in an unwritten constitution and an unelected second chamber) to the same institutional legacy (that of an incomplete bourgeois revolution) that is also taken to account for Britain's peculiar dislocation of financial and industrial capital. The same is not true of the comparative political economists. Taking their lead from Gerschenkron's pioneering analysis, they conceive of finance as "the conduit for all economic activity in market economies" and concentrate accordingly upon the distinctiveness of financial-industrial relations. ${ }^{7}$ These they see as underpinning the specificity of distinct national capitalisms. In so doing they identify clear differences between financial systems, and hence clear differences in the institutional relationships that pertain between industrial and financial capital in different national contexts. Yet their analysis, unlike that of Anderson and Nairn, emphasises institutional similarities and clusterings of national capitalisms which are seen as displaying common characteristics by virtue of the type of financial system they exhibit. Thus the distinctiveness of British capitalism that Anderson and Nairn attribute to British exceptionalism, the comparative political economists attribute to the specificity of a 'capital market-based' financial system that Britain shares with the US. ${ }^{8}$ What in one account is seen as a product of singularity, peculiarity and specificity is, in the other, seen as closely approximating one half of the ideal-typical dualism around which the financial systems of the advanced capitalist economies can be distributed analytically.

In fact much of the literature on comparative capitalisms is centrally structured around the distinction between what, in Gerschenkron's original analysis, were the different developmental trajectories of British and German capitalism respectively, ${ }^{9}$ and what, in more recent work has resolved itself into the distinction between the 'capital market-based' systems of the Anglo-US model and the 'bank-based' systems of the German-Japanese model. ${ }^{10}$ The latter is characterised by a relatively cheap supply of 'dedicated' capital, long-term investment and correspondingly high levels of manufacturing growth, a committed and 'tutelary' (or guardianship) relationship between manufacturers as investors of capital and banks (in the German case, Hausbanken) as suppliers of capital, and an active role for the state in the allocation of credit to private firms. In marked contrast, the former exhibits an arms-length relationship between finance and industry and a limited role for government. It is characterised in turn by short-termism, 'fluid' as opposed to 'dedicated' capital, high target rates of return, the constant threat of hostile take-overs, a lack of committed and long-term investment and correspondingly low levels of manufacturing investment, capacity and growth (see Appendix 1).

If, in Albert Hirschmann's terms, the bank-based financial systems of Germany and Japan are more dialogic and are governed by voice (a sotto voce relationship between manufacturers and financiers perhaps), then the capital market-based system of the Anglophone model is characterised in contrast by a distinct lack of dialogue and communication, by raised voices and ultimately by exit. ${ }^{11}$ Such a depiction of the contours of contemporary capitalism leads its proponents — most of them British or American it should 
be noted - to conclude with Pollin that "the bank-based systems achieve superior performance in three crucial areas: promoting longer time horizons, encouraging financial stability, and providing a framework for the successful implementation of government policy”. ${ }^{12}$

In fact, the diagnosis of the Anglo-US affliction offered by such an analysis is, in many respects, little different from that of the British affliction presented by the likes of Anderson and Nairn, and certainly by Hutton. It points to four distinctive pathologies of a capital market-based financial system for manufacturing capacity, investment and growth: short-termism; risk-aversion; a propensity to acquisitions, mergers and asset-stripping as opposed to rescue strategies where companies fall into difficulties; and a series of adverse consequences for the economy's more general ability to respond to recession. Though closely related it is worth considering each separately and in turn.

\section{$\underline{\text { Short-termism }}$}

Short-termism, widely identified and widely acknowledged as an almost 'natural' quality of a capital market-based financial system, is generally regarded as having the most adverse consequences for the rest of the economy. The allocation of finance on the basis of prices established in competitive capital markets dominated by the desire for liquidity, ${ }^{13}$ together with the overarching concern of institutional investors (such as pension funds) for rapid returns (in line with quarterly assessments of their performance) have conspired to lock the financial system into a mindset dominated by immediate concerns at the expense of longer-term time horizons. ${ }^{14}$ This pervasive short-term ethos is exported to industry in two ways. First, those firms either too small or too new to be able to raise finance by other means, become directly dependent upon financial institutions and are thus forced to internalise the temporally parochial paradigm of their sponsors. As Simon Lee observes, "UK financial institutions have made capital available to industry only at such a prohibitively high cost and for repayment over such a punitively short period of time

that industrial companies have been confronted with one of the highest costs of capital in the world". ${ }^{15}$ Yet even those more established and substantial concerns capable of generating funds internally by raising equity on the stock market are not immune from the infectious short-termism of the financial institutions. For in an active market for corporate control in which hostile take-overs, mergers and acquisitions abound (and for which capital is more readily available), corporate managers can simply not afford the luxury of long-term considerations and must concentrate instead on the short-term performance criteria necessary to stave off predators. ${ }^{16}$

\section{Risk-aversion}


If financial institutions within a capital market-based system display a pathological short-termism, they are at least equally risk-averse, exhibiting a marked preference for guaranteed returns on investment that are, preferably, almost instantaneous. Again this reflects a desire for liquidity and the remarkably short time scale over which investments are expected to pay for themselves. ${ }^{17}$ Since riskier investments, almost by definition, require a more dedicated supply of capital, potentially locking-in otherwise fluid assets, financial institutions in a capital market-based system are reluctant to commit capital to such projects. For as John Zysman notes, "long-term loans must be repaid from future profits and therefore, as a minimum, the bank must make an assessment [a potentially risky projection] of the company's competitive future”. By contrast, "short-term loans can simply be secured against existing company assets". ${ }^{18}$ Short-termism and risk-aversion are thus inextricably interwoven. Moreover, in a climate dominated by the time horizons of the capital markets, risk-aversion is (like short-termism itself) similarly internalised by industry. If small and/or new firms are forced to abandon potentially risky capital investment projects since a supply of venture capital is simply unavailable to them on competitive terms (from financial institutions interested above all in liquidity and immediate profitability), it might be thought that larger firms would be better placed to make more speculative investments. Sadly this is rarely the case. For although such firms are indeed in a position to raise equity, in a highly developed stock market in which the performance of fund managers is judged on a quarterly (even monthly) basis, the raising of equity to fund risky projects is itself a risky venture, exposing the company to the close attentions of predators. In this way, the 'discipline' of the capital markets imposes itself on the entire domestic economy, radically condensing time horizons and militating severely against risk-taking.

\section{Acquisitions, mergers and asset-stripping}

In bank-based financial systems in which the industrial-financial relation is characterised by dedication, reciprocity, mutuality and commitment on both sides, banks tend to respond to management problems within firms by launching often highly intrusive and interventionist rescue strategies. ${ }^{19}$ In capital marketbased systems, by contrast, corporate difficulties tend instead to precipitate a wholly different set of processes as the vultures gather overhead. Here the lack of dedication of financial institutions and the absence of what Stephen Woolcock terms 'relationship banking' becomes cruelly apparent - to the considerable detriment of the company experiencing difficulties.

In such situations, pressure mounts on institutional investors (such as pension funds who may often have a majority stake in the company concerned) to sell their shareholding to predator holding companies. Indeed, where a potential bidder seeks control of the company, the share price will tend to rise (by the so-called 'bidding premium'). This reflects anticipated future profit arising either from projected efficiency gains or, more likely, asset-stripping. Should the take-over bid prove unsuccessful, it is extremely unlikely that the 
share price will remain at its inflated level. This then provides a powerful, and in most cases a sufficient, incentive for institutional investors to accept take-over offers (if not actively to court them) that can only boost their quarterly performance. ${ }^{20}$

Yet were this enticement not in itself sufficient, three further factors exacerbate the tendency of institutional investors to abandon their stake in companies experiencing difficulties to the vultures of the market in corporate control - to "the so-called triple alliance of corporate raiders, junk bond dealers (merchant banks selling-off high yielding bonds created to finance take-overs) and arbitrageurs (people taking positions in companies they predict will be targets for corporate raiders)" ${ }^{21}$ First, bankruptcy laws in Britain, as in the US, severely penalise relationship banking. For direct intervention on the part of a bank in the affairs of an ailing company is likely to result in the bank losing seniority in any subsequent debt claims. This, as Woolcock notes, provides "a fairly powerful disincentive to active intervention". ${ }^{22}$ Second, strict insider trading legislation in Britain and the US also militates against an active role for institutional share-holders. Thus intervention in the affairs of a customer in difficulty is simply not an option for institutional investors (who may, in all likelihood, lack expertise in corporate affairs) if they are to remain within the law. ${ }^{23}$ Finally, deregulation has led to intense competition amongst bank and other financial institutions in Britain in recent years. As Woolcock again observes, "this has tended to undermine any relationship banking that existed. Faced with strong competition, banks have tried to 'poach' new customers, and companies have found an advantage in maintaining links with competing institutions in order to get the best conditions. As a result close relationships, based on trust, between companies and banks have become harder rather than easier to maintain”. ${ }^{24}$ In such a context, rescue strategies are rarely contemplated, confirming a tendency in capital market-based financial systems for acquisitions, mergers and asset-stripping as a response to corporate failure.

\section{$\underline{\text { Responses to recession }}$}

In capital market-based systems, the expectation on manufacturers during a recession is for a large scale shedding of under-utilised capacity and a laying-off of workers - an expectation which companies may choose to disappoint but only at a likely cost to their share price. Thus as John Grieve Smith notes of the UK, "the roles of the suppliers of risk capital and the members of the company (its work-force) have become reversed. If profits are hit, dividends are maintained and employees sacked ... employees bear a much greater risk than the suppliers of capital”. ${ }^{25}$ In bank-based financial systems such as Germany and Japan, by contrast, dedicated investors will seek to preserve jobs and capacity at a short-term cost to themselves of dividends on their investment. 
The consequences for the relative ability of capital market-based economies to respond to recession are severe. They are characteristically slower to recover, since their beleaguered capital stock places them in a poor position to respond to any upturn in demand. Moreover, the loss of sector-specific skills and specialist capital equipment may be difficult to replace, due both to the existence of significant sunk costs and the lack of a dedicated supply of venture capital. ${ }^{26}$ Given this shortfall of manufacturing capacity, a recovery in the domestic economy is likely to result in a significant influx of imports from bank-based economies less hasty to shed capacity during recession and hence better placed to respond to rising demand in the postrecession period. The result, almost inevitably, is a growing trade imbalance and pressure on the currency. Historically, British governments anxious to preserve sterling's role as a reserve currency have responded to such a set of circumstances through deflationary strategies (rather than devaluation), further compounding the problems for manufacturers by weakening international competitiveness and hence sacrificing profits and future investment. ${ }^{27}$ Accordingly, the largely self-fulfilling expectation on the part of capital markets that, in recession, manufacturers will shed workforce and industrial capacity has profoundly adverse consequences for both the ability of the economy to cope with recession and the level of employment over the entire economic cycle.

\section{Putting the 'political' back into comparative political economy}

As the above analysis would perhaps suggest, both the extensive literature on comparative capitalisms and the exceptionalism thesis serve to highlight in clear and unambiguous fashion a series of common institutional and/or more broadly structural weaknesses of the British economy. Whether these are attributed to the incomplete character of Britain's bourgeois revolution and the developmental pathologies of a precocious capitalism, or to a capital market-based financial system that it shares with the US, a stark and remarkably consistent diagnosis of the British affliction is presented. Both accounts provide an important indication of the challenge that confronts New Labour in power if it is to remain true to its manifesto commitment to restore an indigenous investment ethic to British capitalism ${ }^{28}$ and, arguably, to succeed where the more professedly reformist Attlee and Wilson administrations failed. ${ }^{29}$

In the sections that follow we turn our attentions to macroeconomic, industrial and institutional priorities suggestive of a modernising alternative to the pervasive neo-liberal orthodoxy of the times.

New Labour, new monetary policy? 
The central focus of our paper is the need to restore an indigenous investment ethic to British capitalism as a means of inserting sustainable long-term growth dynamics into the domestic economy. ${ }^{30}$ We seek to explore, in what at this stage is still a speculative manner, one way in which it may be possible to alleviate some of the supply constraints which currently impede the flow of capital funds into productive projects. What is required, we suggest, is a re-definition of the very context within which institutional investors operate in Britain, altering in particular the incentives faced by fund managers. By re-casting these incentives in an appropriate manner, we hope that such investors can be persuaded to direct significantly more of their assets into long-term debt in British companies; and that, in turn, these companies will use these new capital funds for long-term productive investments.

If Labour in government is to initiate an investment-led reflation of the British economy, then it is, we argue, to new and previously untried policy approaches that it must turn. For it seems clear that classical instruments of reflationary policy are no longer 'sharp' enough to drive such a policy on their own. Historically, investment potentials were enhanced through monetary expansions. Increases in the domestic money supply would force down the domestic rate of interest, which would in turn decrease the cost of borrowing to fund new capital projects. Moreover, the effect of any increase in the money supply would filter through into the currency markets. An anticipated fall in the rate of interest would depress the value of the domestic currency, thereby providing a further boost to investment. As the pound would fall, so British goods would become more competitive internationally, facilitating expansion into new export markets. In this way, monetary growth creates a clear incentive for British manufacturers to expand and enhance their productive capacity.

Within this framework, the analyst is drawn towards a simple conclusion — the trend rate of investment in the British economy is insufficient to sustain adequate rates of growth; and a clear policy implication — cut interest rates to stimulate further investment. Yet in the current context, such a conclusion would be overly simplistic. For the link between the rate of interest and the rate of productive investment appears to have been weakened in recent times, 'blunting' the efficacy of monetary policy. Domestic interest rates have become ever more sensitive to activity within international financial and currency markets. ${ }^{31}$ As the turnover of these markets has increased exponentially since the world-wide relaxation of capital controls in the $1980 \mathrm{~s},{ }^{32}$ so the latitude of national governments to set their own monetary policies has been progressively eroded. Furthermore, at the same time as an increase in the mobility of financial capital has ensured that governments can only make very marginal adjustments to their monetary stance, the emergence of new financial instruments being traded on the money markets has meant that a far greater change in interest rates is required to secure a desired change in the level of investment demand. 
Quite clearly then, more than mere temporary policy change is required if an indigenous investment ethic is to be restored to British capitalism. Potential capital investors appear to have formed the expectation that, irrespective of the monetary policy observed in the short-run, longer-term tendencies will consistently act to militate against dedicated productive investments. ${ }^{33}$ It is above all necessary, therefore, to change investors' expectations about the future, and this only appears likely in the context of a prior and quite fundamental change in the whole mind-set informing economic policy-making in Britain. This appears all the more pressing now that Gordon Brown has ceded operational responsibility for interest rate policy to the Bank of England. For, as the Financial Times' editorial argued the day after his momentous decision, "[the Bank] is still viewed as the spokesman [sic] for the City"; an impression that subsequent developments would only seem to reinforce. ${ }^{34}$ The fear persists that the combination of the Bank's new role and its old image has, and will continue to be taken by productive interests as a sign that they should expect no lasting change in the cost of borrowing. In short, the de-politicisation of interest rate policy has served further to institutionalise in policy terms the primacy of financial over industrial interests. It is precisely such an expectation which already undermines productive investment.

The economic ‘stability’ which Gordon Brown espouses, therefore, and with which he justified his decision to grant operational independence to the Bank, ${ }^{35}$ can only be interpreted as stability on financial capital's terms. For the tight monetary stance which the Bank of England has already indicated will be necessary to ensure 'financial stability' can only further destabilise indigenous investment potential. It is then still possible, and we would suggest vital (however unfashionable), to justify calls for a looser monetary stance. Yet given that a combination of enhanced financial mobility and innovatory new practices within the financial markets appears to have 'blunted' the efficacy of domestic interest rate policy, this may not of itself be sufficient to close Britain's investment gap. Nonetheless, a relaxation in the monetary stance may go some way towards re-casting the Bank's current reputation for acting as a spokesperson (and now also policy-maker) for the City. This in turn may help to change the expectations of potential investors about the future economic context - expectations on which their willingness to invest depends.

Our concern is with the effect of the dominant monetary policy paradigm in Britain on indigenous productive investment potentials. The general reluctance of British managers to expand productive capacity is in large part a result of perceptions of increased risk within the real economy. The case for an active state to intervene in an attempt to reduce such perceptions must once again be made. Yet as Ciaran Driver argues, currently heightened risk perceptions "have less to do with inflationary expectations than with the prospects for sustainable demand growth" ${ }^{36}$ This in turn suggests that present government interventions in the economy designed, in Gordon Brown's words, "to achieve our objectives for inflation” by making them "the number one priority for policy", are somewhat misdirected. ${ }^{37}$ Indeed, the deflationary monetary stance of the government (reflected in its target inflation rate of 2.5 per cent or below) is perhaps 
in itself the biggest single impediment to a sustainable growth in demand. Expectations of ineffective demand feed through into higher expected risk levels for any given rate of productive investment, which in turn act as a disincentive to investment in new capacity. This is the now familiar story of Britain's recent macroeconomic history — of an ever more vicious circle of under-investment-constrained growth ineffective demand-under-investment and so forth. ${ }^{38}$ Moreover, the new Labour government's pronouncements on economic policy suggest that this peculiarly British cycle of under-investment may well be reproduced in the future. In such a context we put the case for a pro-active government to attempt to construct a distinctively British solution to the problem of British under-investment. In the following pages we offer a series of suggestions for institutional reform. The hope is not only to increase the quantity but equally the quality of new productive investments.

\section{In the dedicated pursuit of inward investment: the cost to indigenous investors}

There is a tendency to assume that the question of the 'quality' of investment is concerned principally, if not exclusively, with the 'dedication' of indigenous investors. This we reject. The issue of quality is an issue of equal importance when assessing the relative merits and demerits of inward investment and of strategies to promote it. Moreover, precisely the same criterion of 'dedication' can be deployed in evaluating the quality of foreign direct investment. At first glance, the image conjured (and now almost synonymous with) the popular narrative of globalistion - that of spatially footloose multi-national corporations operating within a boundary-free international political economy - appears inimical to the notion of capital dedication. Indeed, given that strategies of inward investment are in fact conditional upon such heightened mobility, it is certainly tempting to conclude that inward investment is the very antithesis of dedication.

Yet there are dangerous assumptions submerged within such a conclusion. Though capital mobility there surely is, much of the story of capital's footloose properties is at best a crude exaggeration, at worst a distorting myth. ${ }^{39}$ Even the giants of the multinational world apparently still need to put down roots in their host localities. Furthermore, through the sunk costs they incur during the initial process of re-location, multinationals exhibiting this mobility often tie themselves to their host localities. In so doing they may effectively cut off many of their own subsequent exit options. Yet as we have elsewhere suggested, the myth of 'hyper-mobility' may well be a necessary and certainly a strategic myth for firms to maintain if they wish to maximise their hold over governments. ${ }^{40}$ Capital tends to talk up the possibility of disinvestment through mobility in order to secure a capital-friendly economic climate with as few regulatory restrictions as possible on its activities. ${ }^{41}$ In circumstances in which the threat of capital flight is 
perceived to be a real one, inward investors may well be rewarded (with extra economic subsidies and political favours) merely for staying put.

These subsidies in themselves have the potential to increase the 'dedication' of inward investors through increasing their long-term place-boundedness. ${ }^{42}$ The British government, perhaps more so than any other, has attempted to exploit the possibilities of such subsidisation strategies. ${ }^{43}$ The concomitant expectation is that the future gains which may accrue from subsidising the re-location of inward investors will prove to outweigh the initial subsidisation costs. In most cases, too, inward investors seem more than willing to acquiesce with government in strategies aimed at removing potential exit options in return for initial (and often continuing) subsidies. It would indeed seem as though the dedication of many if not all inward investors can be 'bought' — the price being the perceived cost of dedication itself.

Yet despite the substantial sums devoted to promoting the dedication of inward investors, there is little evidence to suggest a significant increase in the 'quality' of inward investment in Britain. The wage rates being offered by inward investors act as a suitable proxy for the degree to which these re-locating capitals are operating in the high-tech, high-skill, high-wage, high-value added sectors indicative of high quality investments. Consider the Welsh experience. The available evidence shows precious little concentration of inward investment in the high-wage, high-value added sectors. Yet the figures for Wales should, if anything, exaggerate the significance of inward investment to the British economy. For inward investment is more important in the Welsh context in terms both of political rhetoric and economic activity, than it is for any other comparable British region. Moreover, both household disposable income and net pay rates are lower per capita than in any other British region. ${ }^{44}$ However, despite this, we still find that the average wage rates paid by inward investors in Wales are well below the Welsh average. ${ }^{45}$

Such doubts about the 'quality' of the foreign direct investment that successive British governments have worked so assiduously to attract have clear implications for public policy in this area. In the light of the above discussion it is important to consider again (and we would suggest, to review critically) the extent to which government economic policies have been, and continue to be, justified by their ability to attract inward investment. For, not only do these inward investments often appear to be of dubious 'quality'; also, and more importantly, the policies designed to attract such investors simultaneously undermine the promotion of 'dedicated' indigenous investment. As we have been at pains to demonstrate, much of Britain's indigenous investment ethic has been sacrificed on the altar of an overly restrictive monetary policy. Paradoxically, however, it is now these very same dear-money policies which government officials insist must be maintained to provide the 'financial stability' that inward investors like to present as a condition of their re-location. ${ }^{46}$ 
In marked contrast, we wish to see a new context for British economic policy-making within which inward investment does not continue to exert such an overbearing influence. We make no attempt to disguise the distinct normative agenda underpinning this argument. For, wherever inward investment does seem to hold such an influence over policy decisions - and, more importantly, wherever government perceptions are that it should, and should continue to do so - the evidence of recent experience would suggest that the politics of labour market deregulation, competitive undercutting and welfare retrenchment will surely follow. If we are to avoid such current 'inevitabilities' then it is to indigenous investment and institutional innovation that we must turn.

Instilling an indigenous investment ethic amongst institutional investors

'..necessity is the mother of invention'

UK based investors constitute the largest purchasers of portfolio assets in the world. If Labour is to reinstil within the British economy an indigenous investment ethic, it is above all imperative that it considers systematic reform to the institutional, legal and indeed more broadly perceptual environment in which portfolio investors (such as pension funds and insurance companies) operate. Consider pension funds. These 'gross funds', exempt from both income and capital gains tax, represent the largest institutional investors in Britain, contributing significantly to the speculative and short-term bias of the capital markets. Recent figures indicate that UK pension funds accounted for some 70 per cent of Gross National Product in 1993, holding some 52 per cent of shares in quoted companies. ${ }^{47}$ Moreover, as David Blake notes, if we include insurance companies as well, then 'institutional investors' ownership of UK companies' equity has increased from less than 30 per cent in the early 1960s to more than 60 per cent in the early 1990s. It has been estimated that about fifty top fund managers have effective control (51 per cent) of UK industry”. ${ }^{48}$

It might be thought that given the long-term nature of pension fund activity and the relatively stable and predictable character of both their inflows (in the form of employers' and employees' contributions) and their outflows (in the form of actual pension payments), pension funds might be exemplary dedicated longterm investors in domestic manufacturing industry. Sadly nothing could be further from the truth. As Randy Barber and Teresa Ghilarducci observe in an exemplary discussion of the pathologies of portfolio investment in the US that is equally applicable to the UK, "these massive pools of capital are uniquely suited to fund long-term investments because their liabilities are stable, predictable and extended over many decades. However, over the past two decades, pension funds often invested very differently in capital markets as their mostly futile pursuit of above-average returns contributed heavily to 'shorttermism' and speculation in the economy as a whole". As they go on to note, "arguably, their behaviour 
was one of the main detriments to prospects for long-term economic growth, employment creation, and increases in real income". ${ }^{49}$ Despite predictable and long-term liabilities then, pension funds on both sides of the Atlantic display a marked preference for highly liquid assets that they often retain for less than two years.

As well as this pathological aversion to dedicated investment, institutional investors in recent years have channelled vast and growing quantities of capital overseas. This tendency has accelerated significantly since financial deregulation, in particular the abolition of exchange controls on overseas investment on 24 October 1979 (see Tables 1 and 2). 
[as accepted for publication in New Political Economy, 4, 1998]

Table 1: Asset Allocation of UK Pension Funds in 1979 and 1989

\begin{tabular}{|l|cc|}
\hline & $\begin{array}{c}\text { Asset allocation } \\
1979(\%)\end{array}$ & $\begin{array}{c}\text { Asset allocation } \\
1989(\%)\end{array}$ \\
\hline UK equity & 44 & 52 \\
Overseas equity & 6 & 14 \\
UK bonds & 23 & 13 \\
Overseas bonds & 0 & 1 \\
Index linked bonds & 0 & 3 \\
UK property & 22 & 10 \\
Overseas property & 0 & 1 \\
Other & 6 & 8 \\
\hline
\end{tabular}

Source: David Blake, Issues in Pension Funding (Routledge, 1992), p. 20

The above analysis presents a significant, unanswered and, we would suggest, unanswerable case for institutional reform.

Table 2: Overseas Holding of UK Pension Funds 1993

\begin{tabular}{|c|c|}
\hline & $\begin{array}{c}\text { Share of total } \\
\text { investment held in } \\
\text { overseas assets (1993) }\end{array}$ \\
\hline Canada & 9 \\
France & 5 \\
Germany & 3 \\
Japan & 14 \\
UK & 27 \\
US & 4 \\
\hline
\end{tabular}

Although a variety of proposals and reform strategies to maximise the potential benefits of pension funds' investments to the productive economy might be considered we here present merely a basic outline of one such reform strategy.

In the context of such reflections, our aim is not to produce a series of detailed policy proposals designed to address the persistent shortfall of dedicated productive investment in the domestic economy. ${ }^{50}$ Rather, in what follows, we hope to suggest how an alternative conception of the parameters of the politically and 
economically possible liberated from the shackles of a restrictive neo-liberal economic imaginary might inform a more developmental and modernising strategy for the domestic economy. Though such an alternative paradigm might equally inform policy at spatial scales above the national, we restrict ourselves here to domestic considerations. In so doing, our intention is to demonstrate that heightened capital mobility in an era of financial liberalisation need not entail a withering of the political autonomy of the nation(al)-state.

Having identified and catalogued the haemorrhaging of potentially productive institutional assets out of the domestic economy (see Table 2) and the parochialism and short-termism of portfolio investors, it is perhaps appropriate that we begin by considering the prospects for the reform of the investment environment within which institutional investors operate. Set in this context it is certainly tempting to consider removing the status of portfolio investors as gross funds and hence their capital gain and income tax exemption. ${ }^{51}$ Enticing though such a measure might at first appear, however, we fear this would only serve to precipitate an exodus of pension funds from the British capital market and/or a lowering of dividends (likely to be passed directly onto pensioners). More promising, we suggest, is conditional capital gains tax exemption. In order to remain eligible, funds would have to demonstrate a balanced investment portfolio in which a certain percentage of total investments were held long-term (say, over five years). In an indication of the manner in which the investment environment might gradually be re-shaped, this proportion could slowly be revised upwards to a target level, allowing flexible and incremental yet cumulatively significant change. Continued capital gains tax exemption could also be made conditional upon the investment of a certain proportion of fund holdings in UK assets (equity, bonds or property). Administratively simpler, though somewhat less flexible, would be to introduce capital gains tax on short-term gains (and, potentially, on returns on overseas investments), to be compensated for by credits on tax-deductible long-term gains. Credits could also be accumulated for socially-responsible investments (SRIs), economically-targeted investments (ETIs) and special issues of regional bonds designed to promote productive investment in the local and regional economy ${ }^{52}$

In addition to such changes to the architecture of investment, we propose a simple reform to the 1961 Trustee Investments Act governing institutional investors. In a legal redefinition of the notion of the 'best interests' of pension fund beneficiaries, trustees would be required to provide a statement of the criteria by which investment decisions were made and would be expected to be answerable to those criteria in justifying particular investment choices. ${ }^{53}$ The amendment of the existing legislation would also mandate the representation of beneficiaries on the board of trustees, a measure that would have considerably more force were it linked in this way to a revision of the concept of 'best interests' ${ }^{54}$ 
Those ideas that Labour developed in opposition that sought to redress the persistent shortfall of dedicated investment in the productive economy and the need for industrial modernisation have focused in particular on the need for differentiated, but nonetheless complementary, regional industrial development and investment strategies. ${ }^{55}$ Consistent supply-side intervention might here make a virtue of spatially uneven development by promoting managed yet differentiated regional development. In keeping with such a reform agenda that emphasises the need for industrial strategy, supply-side dirigisme, indigenous and differentiated regional growth profiles, and the subordination of the interests of finance to industrial capital, we propose a a series of specifically regional institutional reforms designed to promote investment in the regional economy. Perhaps the simplest and arguably the crudest means to increase investment in the regional economy would be the introduction of regional pension funds. Capitalised initially with public funds, they would, thereafter, be expected to produce profits from their investment activities without further reliance on public resources. In the first instance, they would receive significant tax concessions from the centre, conditional upon an investment of a significant proportion of their assets in regionally-based institutions and projects and on a medium- to long-term basis. The logistical difficulties of introducing such a scheme may, however, prove insurmountable. ${ }^{56}$ Accordingly, a strategy for enticing existing (private) pension funds into a greater regionalisation of their investment activities may ultimately prove more fruitful. Such a strategy would be based again on tax credits. In addition to credits on long-term investment, the regional development agencies (RDAs) proposed in Labour's election manifesto would be encouraged to package regional investment portfolios in the form of regional bonds to be traded to institutional investors such as pension funds. RDAs would here act as investment brokers, intermediating between the regional industry on the one hand and institutional investors on the other. Inclusion of a company's stock within such regional investment bonds might be made conditional upon a democratisation of corporate governance (and hence the principles of 'regional stakeholding').

The above proposals in turn suggest the need for a nexus of regional institutions dedicated to the supply of investment capital on competitive terms to regional industry. It should the goal of the government to ensure that each regional economy have access to a financial sector dedicated to the provision of capital over the long-term. Institutional reform at the regional level would thus see the creation of a series of nonprofitmaking investment and commercial banks which might channel savings and institutional investments to the productive economy. Such dedicated regional financial institutions would be able to provide capital on a long-term and competitive basis to fund regional industrial investment and capital projects that were seen as contributing to the overall competitiveness of the regional economy.

\section{Conclusion}


These reflections constitute a modest attempt to outline some of the measures that an incumbent Labour administration might consider in seeking to restore an indigenous investment ethic to British capitalism. It must be reiterated that it has not been, nor is it, our intention to offer detailed policy outlines in the form of an 'alternative industrial policy manifesto' for Labour in power. Our proposals are speculative and experimental and should be judged accordingly. Our concern has been to stimulate and open up discussion of the nature of the British affliction and the extent of the measures required to address it in the light of the contribution of comparative political economists and contemporary theorists of British exceptionalism.

Labour's 1997 manifesto contains a commitment to combat Britain's significant and enduring problem of under-investment. It is a moot point whether that commitment represents a merely rhetorical reaffirmation of a pledge that it no longer intends to prioritise, or a restatement of an underlying and consistent diagnosis of the principal structural weakness of the British economy which the party in government is dedicated to addressing. The jury, to give New Labour the benefit of the doubt, is still out. Either way, we suggest, some attempt must be made to restore to British capitalism an ethos of dedication and long-term investment and hence to close the capital stock gap with the other major industrialised economies. Otherwise, to echo Michael Kitson and Jonathan Michie, "the alternative is to accept that ... [Britain] cannot compete with these countries and that its comparable competitors are the newly industrialised countries, with all that this entails for domestic living standards and employment opportunities". ${ }^{57}$ Yet, as we have been at pains to demonstrate, to restore such an investment ethic to British capitalism is no easy accomplishment and cannot be achieved in the space of a few years. It requires significant and cumulatively radical institutional reform and a yet more fundamental transformation of the very conceptual and ideational environment within which economic policy and investment decisions are made. These we suggest are necessary, but not in themselves, sufficient conditions to establish in Britain a reinvigorated growth dynamic.

If any aspect of the above diagnosis is correct, then for New Labour and a re-newed and revitalised left, it is time to find out whether necessity is indeed 'the mother of invention'. If it is not, then sadly New Labour's modernisation may have come at the ultimate price of Britain's modernisation. For the time being, however, we remain optimistic.

\footnotetext{
* The authors would like to thank Mark Blyth, Andrew Gamble, Michael Kenny, Mark Wickham-Jones, Daniel Wincott and the referees for New Political Economy for their perceptive and encouraging comments on an earlier version of this paper. Much though it would be nice to blame the usual suspects for all our errors and omissions, they must, as ever, remain protected by the usual veil of disclaimers.
} 
${ }^{1}$ On Labour's 'modernisation', its adoption of a somewhat more consensual tone and its espousal of economic competence couched in broadly neo-liberal terms, see Colin Hay, 'Labour's Thatcherite Revisionism: Playing the Politics of Catch-Up’, Political Studies, Vol. 42, No. 4 (1994), pp. 700-8; 'Anticipating Accommodations, Accommodating Anticipations: The Appeasement of Capital in the 'Modernisation' of the British labour Party, 1987-1992', Politics and Society, Vol. 25, No. 2 (1997), pp. 234-56; 'That Was Then, This is Now: The Revision of Policy in the Modernisation of the British Labour Party, 1992-97', New Political Science, No. 43 (1998), forthcoming; Colin Leys, 'Still a Question of Hegemony', New Left Review, No. 181 (1990), pp. 119-28; Leo Panitch and Colin Leys, The End of Parliamentary Socialism(Verso, 1997).

${ }^{2}$ For a brief genealogy of Labour's conception of industrial strategy and the financial reform required to support it see Simon Lee, 'Finance for Industry', in J. Michie and J. Grieve Smith (Eds), Creating Industrial Capacity: Towards Full Employment (Oxford University Press, 1996), pp. 136-8; see also Andrew Gamble, 'The Labour Party and Economic Management', in M. J. Smith and J. Spear (Eds), The Changing Labour Party(Routledge, 1992).

${ }^{3}$ The flavour of Perry Anderson's contribution is captured in his more recent English Questions (Verso, 1991). See also, Tom Nairn, 'The Twilight of the British State', New Left Review, No. 101/2 (1976), pp. 361; and for a recent 'retrospective’ see Tom Nairn, ‘The Sole Survivor', New Left Review, No. 200 (1993), pp. 41-7.

${ }^{4}$ Will Hutton, The State We're In, revised edition (Viking, 1996); The State to Come (Viking, 1997). Hutton, presumably out of some concern for the broader reception of his ideas, does not publicly acknowledge his debt to Anderson and Nairn's brand of New Left Marxism, though at points in the text the lineage of the argument is unmistakable. See Michael Barrett-Brown, 'The New Orthodoxy', in M. Barrett-Brown and H. Radice, Democracy versus Capitalism, Socialist Renewal Pamphlet No. 4 (European Labour Forum, 1995); Colin Leys, ‘A Radical Agenda for Britain’, New Left Review, No. 212 (1995), pp. 3-13, esp. pp. 4-5; Colin Hay, 'A Sorry State? Diagnosing the British Affliction', Socialism and Democracy, Vol. 11, No. 1 (1997), pp. 87-104, esp. pp. 89-92.

${ }^{5}$ In an indication of the basic compatibility of these apparently rather divergent accounts, Hutton himself relies quite extensively on discussions of the comparative strengths of the German-Japanese 'model'. Pollin too makes explicit reference to affinities between the writings of Nairn and comparative political economists such as Gerschenkron. See Robert Pollin, 'Financial Structures and Egalitarian Economic Policy’, New Left Review, No. 214 (1995), pp. 26-61, p. 30, n. 8.

6 See in particular Michel Albert, Capitalism Against Capitalism (Whurr, 1993); John Zysman, Governments, Markets and Growth: Financial Systems and the Politics of Industrial Change (Cornell University Press, 1983); John Zysman and Laura Tyson (Eds), American Industry in International Competition: Government Policies and Corporate Strategies (Cornell University Press, 1983); Philip G. 
Cerny, 'The Deregulation and Re-Regulation of Financial Markets in a More Open World', in P. Cerny (Ed), Finance and World Politics: Markets, Regimes and States in the Post-Hegemonic Era (Edward Elgar, 1993); Alexander Gerschenkron, Economic Backwardness in Historical Perspective (Harvard University Press, 1962). For applications to the problems of British under-investment see in particular, Pollin, 'Financial Structures and Egalitarian Economic Policy'; Barry Eichengreen, 'Explaining Britain's Economic Performance: A Critical Note', The Economic Journal, Vol. 106, No. 1 (1996), pp. 213-18; Lee, 'Finance for Industry'.

${ }^{7}$ Pollin, 'Financial Structures..', p. 28.

${ }^{8}$ Given Hutton's reliance at various points in his argument on both the exceptionalism thesis and the comparative political economy of Albert in particular, it is perhaps unsurprising that on this he seems to equivocate.

${ }^{9}$ Gerschenkron, 'Economic Backwardness in Historical Perspective', in Gerschenkron, Economic Backwardness..

${ }^{10}$ The distinction between 'bank-based' and 'capital market-based' financial systems is in fact Pollin's. As well as the works already cited see, Marco Orrù, 'Institutional Cooperation in Japanese and German Capitalism', in S. Sjöstrand (Ed), Institutional Change: Theory and Empirical Findings (M. E. Sharpe, 1993); W. Carl Kester, ‘American and Japanese Corporate Governance: Convergence to Best Practice?’, in S. Berger and R. Dore (Eds), National Diversity and Global Capitalism (Cornell University Press, 1996); Stephen Woolcock, 'Competition Among Forms of Corporate Governance in the European Community: The Case of Britain', in op. cit.; Peter A. Gourevitch, 'The Macroeconomics of Microinstitutional Differences in the Analysis of Comparative Capitalism', in op. cit.; Michael E. Porter, 'Capital Choices: National Systems of Investment', in N. R. Goodwin (Eds), As If the Future Mattered: Translating Social and Economic Theory into Human Behaviour (University of Michigan Press, 1996).

${ }^{11}$ Hirshcmann defines his terms in the following way, "by exit, I mean withdrawal from a relationship with a person or organisation ... The direct and more informative way of alerting management is to alert it: this is voice”. Albert O. Hirschmann, 'Exit and Voice: An Expanding Sphere of Influence’, in Hirschmann, Rival Views of Market Society (Harvard University Press, 1986) pp. 78-9; see also Hirschmann, Exit, Voice and Loyalty: Responses to Decline in Firms, Organisations and States (Harvard University Press, 1970).

${ }^{12}$ Pollin, 'Financial Structures..', p. 35.

${ }^{13}$ Matthew Watson, 'Rethinking Capital Mobility: Putting a Different Kind of "P” into Financial Market Regulation', New Political Economy, Vol. 4, No. 2, (1998), fortchoming.

${ }^{14}$ See Mike Buckle and John Thompson, The UK Financial System, Second Edition (Manchester University Press, 1995), pp. 308-14.

${ }^{15}$ Lee, ‘Finance for Industry’, p. 113. 
${ }^{16}$ See in particular, Keith Cowling, 'The Strategic Approach to Economic and Industrial Policy', in K. Cowling and R. Sugden (Eds), A New Economic Policy for Britain: Essays on the Development of Industry (Manchester University Press, 1990).

${ }^{17}$ On which see Stephen Bond and Tim Jenkinson, ‘The Assessment: Investment Performance and Policy’, Oxford Review of Economic Policy, Vol. 12, No. 2 (1996), pp. 1-29; Confederation of British Industry, Realistic Returns: How do Manufacturers Assess New Investment (CBI, 1994).

${ }^{18}$ Zysman, Governments, Markets and Growth, p. 195.

${ }^{19}$ Thus as Dimitri Vittas notes, the banks "have an active part in arranging mergers and take-overs and have occasionally used their strength to prevent the purchase of stakes in German companies by 'undesirable' elements ... the banks have supervised the rescue of a number of companies, saving jobs and gaining considerable goodwill in the process". In a similar vein John Zysman points to the intervention of the banks in the early 1980s to "restructure the troubled Telefunken company and the Deutsche Bank's refusal to allow Mercedes Benz to fall under foreign control" as reinforcing the impression that "the banks patrol the borders of German industry ... mak[ing] possible a more directed process of market-led adjustment”. Dimitri Vittas, Banking Systems Abroad (Inter-Bank Research Organisation, 1978); Zysman, Governments, Markets and Growth, p. 265.

${ }^{20}$ Buckle and Thompson, The UK Financial System, pp. 309-10; Woolcock, 'Competition Among Forms of Corporate Governance in the European Community'; Julian Franks and Colin Mayer, 'Corporate Ownership and Corporate Control: A Study of France, Germany and the United Kingdom', Economic Policy, Vol. 10 (1990), pp. 189-231; W. Carl Kester, 'Industrial Groups as Systems of Contractual Governance', Oxford Review of Economic Policy, Vol. 83 (1992), pp. 24-44.

${ }^{21}$ Cowling, 'The Strategic Approach to Economic and Industrial Policy’, p. 14.

${ }^{22}$ Woolcock, 'Competition Among Forms of Corporate Governance in the European Community', p. 187.

${ }^{23}$ David Blake, Pension Schemes and Pension Funds in the United Kingdom (Clarendon Press, 1995), pp. 486-98; Issues in Pension Funding (Routledge, 1992); Gourevitch, 'The Macropolitics of Microinstitutional Differences’, p. 243.

${ }^{24}$ Woolcock, 'Competition Among Forms of Corporate Governance in the European Community’, p. 187.

${ }^{25}$ John Grieve Smith, 'Rebuilding Industrial Capacity’, in J. Michie and J. Grieve Smith (Eds), Creating Industrial Capacity (Oxford, 1996), p. 19; 'Devising a Strategy for Pay', in J. Michie and J. Grieve Smith (Eds), Employment and Economic Performance: Jobs, Inflation and Growth (Oxford University Press, 1997), p. 216.

${ }^{26}$ A. Dixit, 'Investment and Hysteresis', Journal of Economic Perspectives, Vol. 6, No. 1 (1992), pp. 10732; Michael Kitson and Jonathan Michie, 'Manufacturing Capacity, Investment and Employment', in Michie and Grieve Smith (Eds), Employment and Economic Performance. 
27 Zysman, Governments, Markets and Growth, pp. 172-80; Andrew Gamble, Britain in Decline (Macmillan, 1994); Scott Newton and Dilwyn Porter, Modernisation Frustrated: The Politics of Industrial Decline in Britain Since 1900 (Unwin Hyman, 1988).

${ }^{28}$ Labour Party, Because Britain Deserves Better (Labour Party, 1997) pp. 10-13; see also A New Economic Future for Britain: Economic and Employment Opportunities For All (Labour Party, 1995), esp. ch. 5; Labour Industry Forum, Winning for Britain (Labour Party, 1994), esp. pp. 12-16; Labour Party, Labour's Economic Approach (Labour Party, 1993); Gordon Brown, speech to CBI Annual Conference, (Labour Party, 11 November 1996); Brown, Labour's Macroeconomic Framework, speech to the Labour Finance and Industry Group, (Labour Party, 1995).

${ }^{29}$ There is a voluminous literature on both the Attlee and Wilson's governments ultimately abortive attempts at institutional and industrial modernisation. On the Attlee government see in particular Lewis Johnmann, 'Labour and Private Industry, 1945-51', in N. Tiratsoo (Ed), The Attlee Years (Pinter, 1991); Helen Mercer, 'The Labour Governments of 1945-51 and Private Industry', in Titasoo (Ed), The Attlee Years; Sidney Pollard, The Development of the British Economy, second edition (Edward Arnold, 1992); Nicholas Tiratsoo and Jim Tomlinson, Industrial Efficiency and State Intervention: Labour 1939-51 (Routledge, 1993); Jim Tomlinson, Government and the Enterprise Since 1900 (Clarendon, 1994). For a brief review see Hay, Re-Stating Social and Political Change (Open University Press, 1996), pp. 34-5. On Wilson see Wyn Grant, The Political Economy of Industrial Policy (Butterworth, 1982); Simon Lee, 'Manufacturing' in D Coates (Ed), Industrial Policy in Britain (Macmillan, 1996); Frank Longstreth, 'The City, Industry and the State', in C. Crouch (Ed), State and Economy in Contemporary Capitalism (Macmillan, 1979); Michael Shanks, Planning and Politics: The British Experience, 1960--74 (Allen and Unwin, 1977); S. Young and A. Lowe, Intervention in the Mixed Economy (Croom Held, 1974); Zysman, Government, Markets and Growth, pp. 212-20.

${ }^{30}$ If only to insure dividends to fund social expenditure within a political and discursive climate in which tax increases seem prohibitively unpalatable.

${ }^{31}$ John Grive Smith, 'Rebuilding Industrial Capacity’, in J. Michie and J. Grieve Smith (Eds), Creating Industrial Capacity: Towards Full Employment (Oxford University Press, 1996), p. 13.

${ }^{32}$ Andreas Busch, 'Unpacking the Globalisation Debate: Approaches, Evidence and Data', in C. Hay and D. Marsh (Eds), Demystifying Globalisation (Macmillan, 1998), forthcoming.

${ }^{33}$ Recent events would suggest that potential investors are justified in forming such an expectation. For the 'super-competitive pound' which was a legacy of sterling's ejection from the ERM was only able to offer British firms a short-run competitive advantage. After the initial fall-out of Black Wednesday, the pound has shown a trend appreciation so that it is now at a far less competitive level than it was in September 1992 (reaching on 7 April 1997, for instance, a higher level against the Deutsch-Mark than it had even been while inside the ERM). The upward surge in the value of the pound was given a further 
boost with Gordon Brown's announcement of a 'quasi-independent’ Bank of England. Set in this context it is not difficult to understand why British managers might choose to limit their responses to short-run devaluations, in Bootle's terms, to the 'grossly profitable'.

${ }^{34}$ Financial Times, editorial, 7 May 1997, p. 21.

${ }^{35}$ See Gordon Brown's letter to the Governor of the Bank of England announcing the decision to re-define the institutional arrangement for the setting of interest rates, cited in full in the Financial Times, 7 May 1997, p. 10. See also Gordon Brown, Speech to Labour Party Annual Conference, (Labour Party, 1996); Speech to CBI Annual Conference (Labour Party, 1996).

${ }^{36}$ Driver, 'Tightening the Reins', p. 75.

${ }^{37}$ Gordon Brown, Speech to the CBI Annual Conference (Labour Party 1996). It is more than a little ironic that the present Chancellor made his boldest anti-inflation commitments of the pre-election campaign, in claiming for Labour the mantle of the new 'pro-business party' in this speech to the CBI Annual Conference.

${ }^{38}$ We have argued that a combination of: i) a domestic monetary policy so tight that British investors have to pay an interest rate premium relative to that of their industrial competitors overseas in funding new investments in productive capacity [see Appendix 2]; ii) an exchange rate policy which has left the pound structurally over-valued in relation to the export/import capacity of the British economy (to the detriment of export market share); and, iii) the expectation that the present interest and exchange rates stance will not be changed in the near future; has served to undermine substantially the inclination of managers to expand and modernise productive capacity. The ensuing shortfall of investment impedes indigenous growth rates [see Appendix 1]. In turn, slow growth rates tend to encourage in consumers the expectation that a recession is imminent, further suppressing demand. As we have already seen, when domestic demand appears to be constrained, investors build this knowledge into their expectations about the future investment context in such a way so as to further undermine investment potentials. For if they believe that there will be insufficient market demand to match their increased output potential once they have invested in new capacity, then it is unlikely that they will undertake that investment in the first place. In short, prevailing market conditions on the demand-side will render investment too risky. The cycle of underinvestment—low growth—insufficient demand — underinvestment is triggered once more, but this time at an even lower trend level of investment, growth and demand.

${ }^{39}$ For a brilliant rebuttal of such crude, and popular, globalisation mythologies see Robert Wade, 'Globalisation and its Limits: Reports of the Death of the National Economy are Greatly Exaggerated', in Berger and Dore (Eds), National Diversity and Global Capitalism.

${ }^{40}$ See Hay, 'Anticipating Accommodations', pp. 242-3; Watson 'The Changing Face of Macroeconomic Stabilisation'. 
${ }^{41}$ The example of Hoover provides an interesting illustration of the strategies of 'competitive arbitrage' faciliatated by threatened mobility. The company recently announced plans to close a third of its plants in Europe but omitted to declare which ones until the full range of 'enticements to dedication' had been presented by 'host' governments. See Christian Belleck, 'Reeling in the Transnationals: Governments do Have the Machinery to Influence Transnational's Behaviour', New Economy, Vol. 4, No. 1 (1997), pp. 1721, esp. p. 19.

${ }^{42}$ See the discussion of the quite deliberate strategies to increase the place-boundedness of Nissan in Sunderland in Colin Hay and Bob Jessop, 'The Governance of Local Economic Development and the Development of Local Economic Governance', Urban Affairs Review (forthcoming).

${ }^{43}$ The single exeption within Europe may be Ireland. See for instance, Neil Hood and James H. Taggart, 'German FDI in the UK and Ireland: Survey Evidence’, Regional Studies, Vol. 31, No. 2 (1997), pp. 13950.

${ }^{44}$ See 'Regional Economic Indicators', Economic Trends, No. 509 (March 1996), pp. 14-19.

45 Jonathan Morris, 'McJobbing a Region: Industrial Restructuring and the Widening Socio-economic Divide in Wales', in R. Turner (Ed), The British Economy in Transition: From the Old to the New (Routledge, 1995), pp. 46-66; p.60. See also Watson 'The Changing Face of Macroeconomic Stabilisation'.

${ }^{46}$ For evidence of bipartisan consensus on this issue see Kenneth Clarke's last budget speech as Chancellor of the Exchequer, 26 November 1996, and also the series of speeches made by Gordon Brown, both before and after the general election, on the subject of 'financial stability'.

${ }^{47}$ HM Treasury, Overseas Investment and the UK: Explanations, Policy Implications, Facts and Figures (HMSO, 1996); Share Ownership: The Share Register Survey Report (HMSO, 1993); Stephen R. Bond, Michael P. Devereuz and Malcolm J. Gammie, 'Tax Reform to Promote Investment', Oxford Review of Economic Policy, Vol. 12, No. 2 (1996), pp. 109-17.

${ }^{48}$ Blake, Pension Schemes and Pension Funds in the United Kingdom, p. 485.

${ }^{49}$ Randy Barber and Teresa Ghilarducci, 'Pension Funds, Capital Markets, and the Economic Future' in G. A. Dymski, G. Epstein and R. Pollin (Eds), Transforming the US Financial System(M. E. Sharpe, 1993), p. 288; for a similar interpretation of the pension fund activity in the UK see Andrew Cosh, Alan Hughes and Ajit Singh, 'Take-overs and Short-termism: Analytical and Policy Issues in the UK', in Take-overs and Short-termism in the UK, Industrial Policy Paper No. 3 (Institute for Public Policy Research, 1990).

${ }^{50}$ Though see Colin Hay and Matthew Watson, 'Necessity is the Mother of Invention: Restoring an Indigenous Investment Ethic to British Capitalism', unpublished paper, Department of Political Science and International Studies, University of Birmingham. 
${ }^{51}$ See James R. Crotty and Don Goldstein, 'Do US Financial Markets Allocate Credit Efficiently? The Case of Corporate Restructuring in the 1980s', in Dymski et al (Eds), Transforming the US Financial System.

${ }^{52}$ For a more detailed analysis of all of these reform strategies and further proposals for a regionalisation of investment activity in Britain see Hay and Watson, 'Necessity is the Mother of Invention'; on SRIs and ETIs see Barber and Ghilarducci, ‘Pension Funds and Capital Markets’, pp. 298-305; Severyn Bruyn, The Field of Social Investing (Cambridge University Press, 1987).

${ }^{53}$ For similar proposals for the US see Jane W. D’Arista and Tom Schlesinger, 'The Parallel Banking System', in Dymski et al (Eds), Transforming the US Financial System, Pollin, 'Financial Structures and Egalitarian Economic Policy', p. 51.

${ }^{54}$ See also Barber and Ghilarducci, 'Pension Funds, Capital Markets and the Economic Future’; Fred Block, ‘Capitalism Without Class Power’, Politics and Society, Vol. 20, No. 3 (1992), pp. 277-303; Will Hutton, 'Failings of the British Financial System', in S. Milner (Ed), Could Finance do More for British Business? (Institute for Public Policy Research, 1995); Porter, 'Capital Choices’.

${ }^{55}$ See in particular Bryan Gould, 'Introduction' in Cowling and Sugden (Eds), A New Economic Policy for Britain; Labour Industry Forum, Winning for Britain; Regional Policy Commission, Renewing the Regions: Strategies for Regional Economic Development (Regional Policy Commission, 1996).

${ }^{56}$ For a discussion of these see Hay and Watson, 'Necessity is the Mother of Invention'.

${ }^{57}$ Kitson and Mitchie, ‘Manufacturing Capacity, Investment and Employment’, p. 46. 


\section{Appendix 1}

Although the relationships between savings and investment, and investment and growth cannot be reduced to simple linear models of cause and effect, Angus Maddison's growth accounting statistics do nonetheless point to some clear associations. Both associations are positive, with high savings/GDP ratios correlated with high investment/GDP ratios, and high rates of investment correlated with high rates of growth. [Source: Angus Maddison, Explaining the Economic Performance of Nations: Essays in Time and Space (Edward Elgar, 1995), pp. 171-80]

Table A.1.1: Total gross sa vings as a ratio of GDP at current market prices

\begin{tabular}{|l|c|c|c|}
\hline & $\mathbf{1 9 6 0 - 7 3 ( \% )}$ & $\mathbf{1 9 7 4 - 8 0} \mathbf{( \% )}$ & $\mathbf{1 9 8 1 - 8 7}(\mathbf{\% )}$ \\
\hline U.K. & 19.5 & 20.9 & 17.5 \\
\hline Canada & 23.4 & 22.7 & 20.4 \\
\hline France & 26.8 & 24.9 & 20.0 \\
\hline Germany & 28.6 & 24.1 & 24.0 \\
\hline Japan & 36.1 & 33.0 & 32.8 \\
\hline Korea & 10.1 & 24.3 & 31.0 \\
\hline U.S.A. & 19.7 & 19.7 & 16.7 \\
\hline
\end{tabular}

Table A.1.2: Gross fixed domestic investment as a ratio of GDP at current market prices

\begin{tabular}{|l|c|c|c|}
\hline & $\mathbf{1 9 6 0 - 7 3 ( \% )}$ & $\mathbf{1 9 7 4 - 8 0} \mathbf{( \% )}$ & $\mathbf{1 9 8 1 - 8 7}(\mathbf{\%})$ \\
\hline U.K. & 17.9 & 18.8 & 16.5 \\
\hline Canada & 22.4 & 23.6 & 21.2 \\
\hline France & 23.8 & 23.5 & 20.2 \\
\hline Germany & 24.9 & 21.1 & 20.2 \\
\hline Japan & 32.6 & 31.7 & 29.2 \\
\hline Korea & 18.9 & 29.4 & 28.6 \\
\hline U.S.A. & 17.8 & 18.4 & 17.7 \\
\hline
\end{tabular}

Table A.1.3: Rate of growth of GDP per capita (annual average compound growth rate)

\begin{tabular}{|l|c|c|}
\hline & $\mathbf{1 9 5 0 - 7 3 ( \% )}$ & $\mathbf{1 9 7 3 - 8 9 ( \% )}$ \\
\hline U.K. & 2.5 & 1.8 \\
\hline Canada & 2.9 & 2.5 \\
\hline France & 4.1 & 1.8 \\
\hline Germany & 4.9 & 2.0 \\
\hline Japan & 8.0 & 3.1 \\
\hline Korea & 5.2 & 6.4 \\
\hline U.S.A. & 2.2 & 1.6 \\
\hline
\end{tabular}


[as accepted for publication in New Political Economy, 4, 1998]

Table A.1.4: Standardised levels of sa vings, investment and growth

\begin{tabular}{|l|c|c|c|}
\hline & $\begin{array}{c}\text { Rank on Maddison's scale } \\
\text { re: standardised level of } \\
\text { savings 1960-1987 }\end{array}$ & $\begin{array}{c}\text { Rank on Maddison's scale } \\
\text { re: standardised level of } \\
\text { fixed investment 1960- } \\
\mathbf{1 9 8 7}\end{array}$ & $\begin{array}{c}\text { Rank on Maddison's scale } \\
\text { re: standardised annual } \\
\text { rate of growth 1950-1989 }\end{array}$ \\
\hline U.K. & 6 & 7 & 6 \\
\hline Canada & 5 & 5 & 5 \\
\hline France & 4 & 4 & 4 \\
\hline Germany & 2 & 3 & 3 \\
\hline Japan & 1 & 1 & 1 \\
\hline Korea & 3 & 2 & 2 \\
\hline U.S.A. & 7 & 6 & 7 \\
\hline
\end{tabular}




\section{Appendix 2}

A central claim of this paper is that Britain needs a new monetary policy paradigm in order to stimulate new investment activity. This claim is based on the assumption that the British economy operates to a tighter monetary policy than the economies of the 'national capitalisms' which consistently out-perform Britain in terms of growth rates. The following figures offer evidence to support these claims. Table A.2.1 shows the observed levels of British interest rates (both short and long) in comparative perspective with those of the United States, Japan and Germany for the years 1987-1996. The table reveals that Britain's monetary stance has indeed been tighter in these years than it has been elsewhere (as shown by the higher rates of interest prevailing throughout this period). Table A.2.2 moves on to cast light on the size of the interest rate premium that potential British investors have to pay in relation to their counterparts in the United States, Japan and Germany.

Table A.2.1: Interest rates in comparative perspective: Britain tight monetary stance

\begin{tabular}{|l|c|c|c|c|c|c|c|c|}
\hline & \multicolumn{2}{|c|}{ U.S.A. } & \multicolumn{2}{c|}{ Japan } & \multicolumn{2}{c|}{ Germany } & \multicolumn{2}{c|}{ U.K. } \\
\hline & $\begin{array}{c}\text { Short } \\
\text { Interest } \\
\text { Rate }\end{array}$ & $\begin{array}{c}\text { Long } \\
\text { Interest } \\
\text { Rate }\end{array}$ & $\begin{array}{c}\text { Short } \\
\text { Interest } \\
\text { Rate }\end{array}$ & $\begin{array}{c}\text { Long } \\
\text { Interest } \\
\text { Rate }\end{array}$ & $\begin{array}{c}\text { Short } \\
\text { Interest } \\
\text { Rate }\end{array}$ & $\begin{array}{c}\text { Long } \\
\text { Interest } \\
\text { Rate }\end{array}$ & $\begin{array}{c}\text { Short } \\
\text { Interest } \\
\text { Rate }\end{array}$ & $\begin{array}{c}\text { Long } \\
\text { Interest } \\
\text { Rate }\end{array}$ \\
\hline 1987 & 6.82 & 8.39 & 4.15 & 4.64 & 4.03 & 6.14 & 9.77 & 9.69 \\
\hline 1988 & 7.65 & 8.84 & 4.43 & 4.77 & 4.34 & 6.46 & 10.41 & 9.62 \\
\hline 1989 & 8.99 & 8.50 & 5.31 & 5.16 & 7.12 & 6.90 & 13.96 & 10.11 \\
\hline 1990 & 8.06 & 8.55 & 7.62 & 6.90 & 8.49 & 8.66 & 14.82 & 11.56 \\
\hline 1991 & 5.87 & 7.86 & 7.21 & 6.40 & 9.25 & 8.42 & 11.58 & 10.08 \\
\hline 1992 & 3.75 & 7.00 & 4.28 & 5.24 & 9.52 & 7.80 & 9.74 & 9.09 \\
\hline 1993 & 3.22 & 5.86 & 2.83 & 4.18 & 7.28 & 6.47 & 5.99 & 7.40 \\
\hline 1994 & 4.67 & 7.08 & 2.12 & 4.20 & 5.36 & 6.86 & 5.57 & 8.01 \\
\hline 1995 & 5.93 & 6.57 & 1.12 & 3.39 & 4.53 & 6.82 & 6.77 & 8.16 \\
\hline 1996 & 5.41 & 6.43 & 0.48 & 3.03 & 3.31 & 6.21 & 6.11 & 7.79 \\
\hline
\end{tabular}

Source: Financial Times, 8 April 1997, p. 6; Datastream.

Short-term interest rates: period averages of U.S.A. - 90 day commercial paper; Japan — 3 month certificates of deposit; Germany - 3 month Fibor; U.K. - 3 month Libor.

Long-term interest rates: period average yields on 10-year benchmark government bonds. 
Table A.2.2: Interest rate premiums on investment

\begin{tabular}{|l|c|c|c|c|c|c|c|c|c|c|}
\hline & \multicolumn{3}{|c|}{$\begin{array}{c}\text { Short } \\
\text { Inter est Rates }\end{array}$} & \multicolumn{2}{c|}{$\begin{array}{c}\text { U.K. Short } \\
\text { Inter est Rate } \\
\text { Premium, over: }\end{array}$} & \multicolumn{3}{c|}{$\begin{array}{c}\text { Long } \\
\text { Interest Rates }\end{array}$} & \multicolumn{2}{c|}{$\begin{array}{c}\text { U.K. Long } \\
\text { Inter est Rate } \\
\text { Premium, over: }\end{array}$} \\
\hline & U.K. & Average & Best & Average & Best & U.K. & Average & Best & Average & Best \\
\hline $\mathbf{1 9 8 7}$ & 9.77 & 5.00 & 4.03 & 4.77 & 5.74 & 9.69 & 6.39 & 4.64 & 3.30 & 5.05 \\
\hline $\mathbf{1 9 8 8}$ & 10.41 & 5.47 & 4.34 & 4.94 & 6.07 & 9.62 & 6.69 & 4.77 & 2.93 & 4.85 \\
\hline $\mathbf{1 9 8 9}$ & 13.96 & 7.14 & 5.31 & 6.82 & 8.55 & 10.11 & 6.85 & 5.16 & 3.26 & 4.95 \\
\hline $\mathbf{1 9 9 0}$ & 14.82 & 8.06 & 7.62 & 6.76 & 7.20 & 11.56 & 8.04 & 6.90 & 3.52 & 4.66 \\
\hline $\mathbf{1 9 9 1}$ & 11.58 & 7.44 & 5.87 & 4.14 & 5.71 & 10.08 & 7.56 & 6.40 & 2.52 & 3.68 \\
\hline $\mathbf{1 9 9 2}$ & 9.74 & 5.85 & 3.75 & 3.89 & 5.99 & 9.09 & 6.68 & 5.24 & 2.41 & 3.85 \\
\hline $\mathbf{1 9 9 3}$ & 5.99 & 4.44 & 2.83 & 1.55 & 3.16 & 7.40 & 5.50 & 4.18 & 1.90 & 3.22 \\
\hline $\mathbf{1 9 9 4}$ & 5.57 & 4.05 & 2.12 & 1.52 & 3.45 & 8.01 & 6.43 & 4.20 & 1.58 & 3.81 \\
\hline $\mathbf{1 9 9 5}$ & 6.77 & 3.86 & 1.12 & 2.91 & 5.65 & 8.16 & 5.59 & 3.39 & 2.57 & 4.77 \\
\hline $\mathbf{1 9 9 6}$ & 6.11 & 3.07 & 0.48 & 3.04 & 5.63 & 7.79 & 5.22 & 3.03 & 2.57 & 4.76 \\
\hline
\end{tabular}

Note: 'Average' interest rate denotes the standardised mean for U.S., Japanese and German interest rates.

'Best' interest rate denotes the lowest observed rate in the three economies. ('Short' and 'long' interest rates are defined as above.) 